\title{
АЗОТСОДЕРЖАЩИЕ ГЕТЕРОЦИКЛИЧЕСКИЕ ПРОИЗВОДНЫЕ КАМФОРЫ С ШИРОКИМ СПЕКТРОМ ПРОТИВОВИРУСНОЙ АКТИВНОСТИ
}

\author{
К.С. Ковалева', В.В. Орешко1,3, О.И. Яровая', Д.Н. Щербаков², \\ А.А. Зайковская ${ }^{2}$, Л.Н. Шишкина ${ }^{2}$, Н.Ф. Салахутдинов' \\ ${ }^{1}$ Новосибирский институт органической химии им. Н.Н. Ворожцова, \\ 630090, Россия, г. Новосибирск, пр. Академика Лаврентьева, д. 9. \\ 2ФБУН ГНЦ ВБ «Вектор» Роспотребнадзора, 630559, Россия, г. Кольцово. \\ ${ }^{3}$ Новосибирский Государственный Университет, \\ 630090, Россия, г. Новосибирск, ул. Пирогова, д. 1.
}

DOI:10.19163/MedChemRussia2021-2021-218_E-mail: kseniya.kovaleva3103@yandex.ru

Распространение инфекционных болезней зачастую имеет серьезные социально-экономические последствия, а в ряде случаев может повлечь за собой возникновение чрезвычайных ситуаций. Анализ пандемии новой коронавирусной инфекции подтверждает серьезную опасность вирусных заболеваний. За последние десятилетия удалось добиться значительного прогресса в разработке противовирусных агентов, сертифицированных для лечения широкого ряда заболеваний. Однако химиотерапия пока практически бессильна перед целым рядом инфекций. В связи с этим поиск новых противовирусных агентов по сей день является актуальной проблемой и важной задачей медицинской химии. Перспективными стартовыми молекулами для поиска новых лекарственных препаратов являются терпеноиды. Известно, что азотсодержащие производные природных бициклических монотерпеноидов обладают широким спектром противовирусных свойств [1]. В ходе работы из (+)-камфоры был получен соответствующий гидразон, на основе которого были синтезированы конъюгаты с эпоксиизоиндолами 1, N-замещенные 2-иминотиазолидин-4-оны 2 и 2,3-дигидротиазолы 3. Синтезированные соединения проявили широкий спектр противовирусной активности.

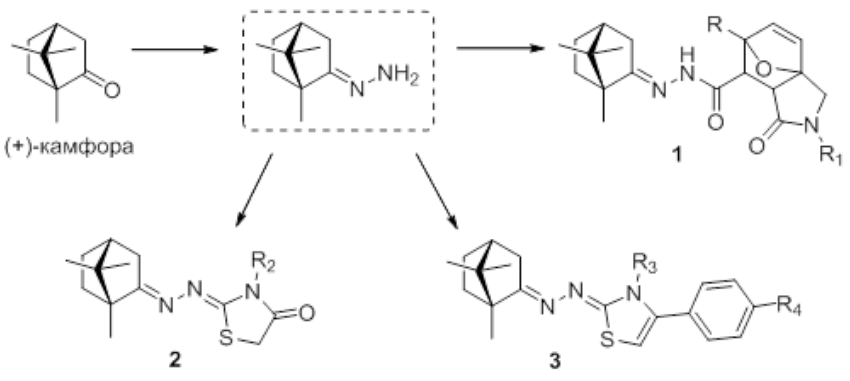

Работа поддержана грантом Минобрнауки России № 075-15-2020-777.

\section{Литература}

[1] О.И. Яровая, Н.Ф. Салахутдинов, Успехи химии, 2021, Т. 90, N 4, 488-510. 